\title{
HOW TO INCREASE PRODUCTIVITY IN LODGING SERVICE INDUSTRY IN JAPAN - REFERRING UNIQUE CASES OF BUSINESS HOTEL COMPANIES
}

\author{
Tsutomu Yoshioka ${ }^{20}$
}

\begin{abstract}
Low productivity is regarded as a problem for Japan's service industry, especially in the lodging services. As a matter of course, improvement of productivity of this industry is required urgently. Therefore, it is necessary to clarify what the academic research has shown about the productivity of lodging services so far. In addition, there are companies that maintain high productivity in this service, it is necessary to derive implications from these cases and to consider the direction of research on productivity of lodging services in the future.
\end{abstract}

Key words: Value Added, Labor hours, Approach Operation, Convenience, Increasing Revenue

\section{INTRODUCTION}

\section{'Business Hotel' in Japan}

"Business hotels" in Japan are called "hotel focused in accommodation". Many business hotels do not have restaurants, and there are many business hotels that do not have ballrooms, bars, fitness gyms or swimming pools. In other words, it can be said that the purpose of business hotels is simply to stay or sleep.

Rooms are often single rooms with a size of 9-12 square meters, with only a bed, a small desk and a small bathroom. The target customersarepeople who are on their business trips. In recent years, the use by not only business travelers but also tourists has increased. The reason is that the accommodation fee is affordable. Recently, this type of hotelsare increasing in Japan.

\section{Problems and Objectives}

The low labor productivity in the Japanese service industry, especially lodging services, is regarded as a problem. Table 1 shows labor productivity in the seven leading OECD countries.

\footnotetext{
${ }^{20}$ Associate Professor, Faculty of International Tourism Management, Toyo University, 528-20 Hakusan Bunkyo-ku Tokyo112-8606, Japan.
} 
Tab. 1. Labor Productivity of 7 advanced (or developed) countries in OECD

\begin{tabular}{|c|c|c|c|c|}
\hline \multirow{2}{*}{ Rank } & \multicolumn{2}{|c|}{ Labor Productivity per person } & \multicolumn{2}{c|}{ Labor Productivity per labor hour } \\
\cline { 2 - 5 } & Country & $($ US\$) & Country & (US\$) \\
\hline 1 & United States & 127,075 & United States & 72.0 \\
\hline 2 & France & 106,998 & Germany & 69.8 \\
\hline 3 & Italy & 104,179 & France & 67.8 \\
\hline 4 & Germany & 100,940 & Italy & 55.5 \\
\hline 5 & Canada & 93,093 & Canada & 53.7 \\
\hline 6 & United Kingdom & 89,674 & United Kingdom & 53.5 \\
\hline 7 & Japan & 84,027 & Japan & 47.5 \\
\hline
\end{tabular}

Source: Japan Productivity Center (2018) adapted by the author

Table-1 shows the labor productivity in Japan is lower than in other countries. Figure-1 shows changes in labor productivity by industry classification in Japan. And Figure-1 shows that the labor productivities of "lodging" services, and "food and beverage" services, closely related to lodging services, arequite low in Japan.

The problem of low labor productivity of lodging services, needs to be solved. The Japanese government has taken various actions to solve this problem. However, it has not been solved at all. Therefore, it is clear that academic research in this field is necessary. Furthermore, there are hotel companies in Japan that maintain high labor productivity. So, what are the implications that can be derived from cases of companies? The purpose of this paper is to clarify these points.

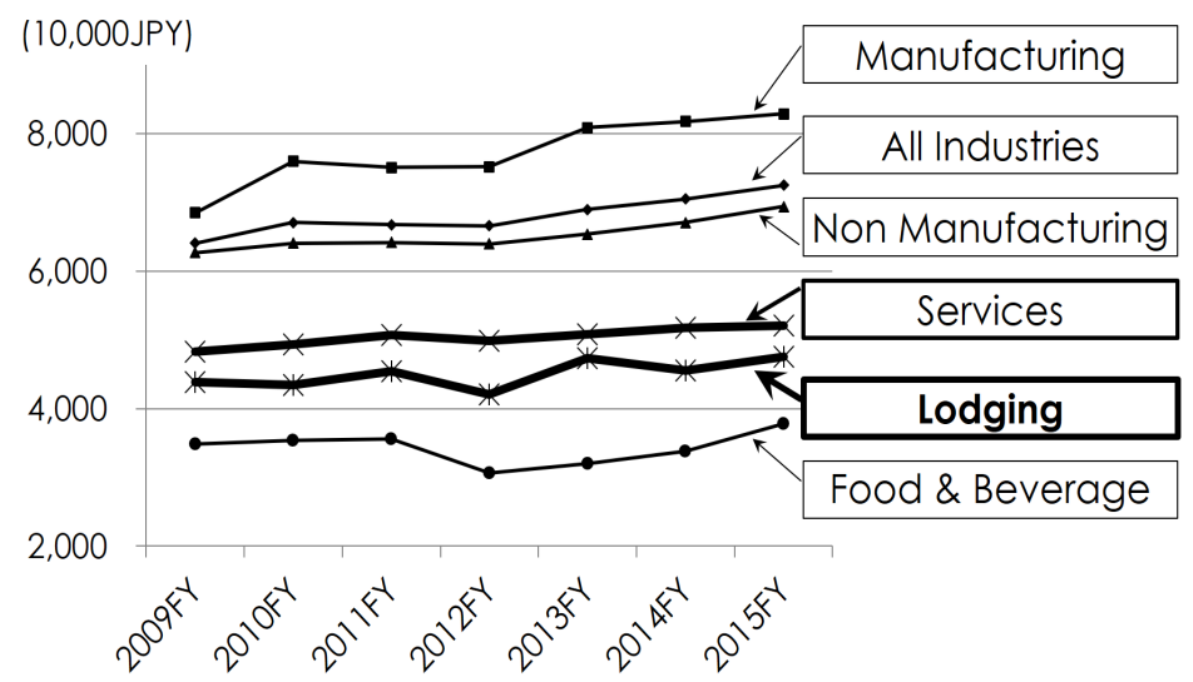

Fig. 1. Labor Productivity by industries in Japan

Source: Policy Research Institute, Ministry of Finance, Japan (2015) adapted by the author 


\section{METHODOLOGY}

In this study, the mathodology of case studies is used. This is because it is difficult to collect data on individual companies or individual hotels on labor productivity in Japan. Also, in this study, which aims to derive implications from successful cases, case studies are considered appropriate.

This study uses the cases of two hotel companies. One is a company that operates a number of business hotels in Japan (Company S). This company also operates hotels overseas. The other is a company (Company G) that operates five business hotels in Japan.

\section{PREVIOUS RESEARCHES}

\section{Productivity}

Stewart and Johns (1996) states that productivity may be broadly defined as the ratio of input to output. Labor productivity is generally calculated by the following formula.

$$
\begin{aligned}
& \text { Labor productivity per a labor } \quad=\frac{\text { Value added }}{\text { Number of labors }} \\
& \text { or } \\
& \text { Labor productivity per a labor hour }=\frac{\text { Value added }}{\text { Total working hours }}
\end{aligned}
$$

In addition, OECD: Organisation for Economic Co-operation and Development (2001) lists the following two labor productivity formulas.

Quantity index of gross output / Quantity index of labour input Quantity index of value added / Quantity index of labour input

From these formulas, it can be said that "value added" is an important factor in labor productivity. According to Kajiura (2016) and Mizuno (2019), value added includes addedvalue by companies. In addition, value added is simply measured by the formula "Revenue-Pre-benefit costs". 


\section{CASES AND DISCUSSIONS}

\section{\#1: Denominator Decrease (S company)}

\section{Introduction of S company}

Company $\mathrm{S}$ is a business hotel chain company. It has more than 100 hotels, mainly in Japan. Also, it is a famous hotel about customer satisfaction.

\section{Case \#1-1; Legs of beds}

One day, a housekeepersaid "No need bed legs!". She thought that if there were no legs for the beds, there was no need to clean under the beds. This is because there is no space for dust to enter under the beds. Also, it is impossible for the guest to drop something and not find it. In other words, because the bed has legs, she has to check under the bed every day.This opinion reached the president of this company. So the president decided to cut off the legs of the beds.

What happened as a result? In housekeeping work, the time required to clean guestrooms was reduced by several minutes. This is because the time to move the bed to check under, and to clean it is no longer necessary.This event is examined with simulation data.

- This hotel has 100 rooms, and the average annual occupancy rate is $90 \%$.

- Housekeeper hourly wage is US $\$ 10$

- Then, 90 rooms will be cleaned per day.

- Since the working time per room can be reduced by 3 minutes, $90 * 3$ can reduce 270 minutes (4.5 hours) for a day at one hotel.

- Since 4.5 hours per day, $4.5 * 365=1,642.5$ hours can be shortened in one year.

- Since 1,642.5 hours per year, labor costs of $1,642.5 * 10=$ US $\$ 16,425$ can be reduced

- If the same thing is realized at 100 facilities (hotels), labor costs of US \$ $1,642,500$ can be reduced.

\section{Case \#1-2; Three "NO"s}

This hotel has no physical keys to the rooms. Also, there is no food or drinks in the refrigerator or mini bar in the guestroom. Furthermore, there are no telephones in the guestrooms. Guests will receive a receipt at check-in. The receipt is marked with a 6-digit number. In addition, the door knob in the guestroom has a numeric keypad. Guests can enter the guestroom by opening the door of the guestroom by entering the number on the receipt. 
There are vending machines of beverages near the the check-in counter and the floors where the guestrooms are located. Guests can also purchase food and drinks at convenience stores near the hotel and put them in the refrigerator in the room.

There are no telephones in the guestrooms, but most of the guests have mobile phones recently. If the guests need to be contact the hotel, guests can contact with their mobile phones. The same applies when calling outside the hotel.

This three "no"s means that no checkout procedure is required. Guests do not need to return the key when leaving the hotel. This is because there is no key. Guests do not have to pay anything. This is because there are no external telephones, meals at restaurants in the hotel, drinks in the minibar or refrigerator that are subject to liquidation.

For the hotel, there is no need for checkout procedures, so employees do not have to wait at the front desk. In fact, there was no one at the front desk when staying at a hotel of Company S. Guests can leave the hotel at their desired time.

Since there is no need to place employees at the front desk, labor costs can be reduced. During the morning hours, many other hotels must have employees to check out. This is unnecessary.Thesepointsare examined with simulation data.

- Assume that two people at the front desk would normally be required during the morning hours, and that the working time per person at the front desk is 3 hours.

- Assume the hourly wage for front desk employees is US $\$ 10$

- Then, $2 * 3 \mathrm{~h} * 365$ days $=2,190$ hours can be saved in one year.

- Since 2,190 hours per year, the labor cost of 2,190 h* \$10=US \$21,900 has been reduced.

- If the same thing is realized at 100 facilities (hotels), labor costs of US \$ 2,190,000 can be reduced.

\section{\#2: Numerator Increase (G company)}

\section{Introduction of G company}

Company $\mathrm{G}$ is a business hotel chain company. The company operates five hotels in an area slightly away from central Tokyo. In addition, hotels in this company are known for their high repeat rate (reuse rate of guests). 


\section{Case \#2-1; Approach Operation}

Company G has a customer service policy called "approach operation". This "approach and operation" is a policy that employees approach (contact) the guest actively and as often as possible.

In recent years, business hotels have increased rapidly in Japan. Most of them tend to exclude communication with guests. This policy is said to reduce labor costs. The guest who uses the business hotel is not to enjoy staying and do something like swiming, eating or drinking at the hotel but to stay, in other words, to sleep. Therefore, reducing communication with guests is not a problem, but rather welcomed.However, Company $\mathrm{G}$ actively provides opportunities to interact with guests, or to take care of guests when not requested, contrary to the general policy.

One day when a housekeeper was cleaning the room, she found an empty bag of cold medicine on the table. She thought, "The guests in this room may have a cold". So she added extra blankets to the room, placed more free mineral water than usual, and placed a humidifier in the room. Of course, this was done despite nothing being requested by the guests.

What happened the next morning after the guest returned to the room. At the time of check-out, the guest said that he was thankful at the front desk and was surprised to take care of him even though he had not requested it. Moreover, the guest made a reservation for the next business trip. Naturally, company $G$ has acquired further revenue opportunities.

\section{Case \#2-2; Pursuing convenience for guests by a refrigerator}

At this hotel, soon after guests checked in, most of them went down and went out immediately after going to the room. A young employee looked at the situation and thought, "Why are guests going out soon?" And often observed customers returning to the hotel.

The guest then went to the drug store next to the hotel and found out that they were buying beverages. This hotel has vending machines of beverages. However, drugstores sell drinks at lower prices than vending machines. Therefore, the guest was going out.

The young staff thought that this was inconvenient for guests. So he asked a beverage bottler company to rent a refrigerator. The refrigerator was installed in front of the receptioncounter and bottled or caned drinks were sold at the front desk. 
Of course, they were sold at the same price as a drugstore. The guest could buy a drink at check-in without inconvenience going out after check-in.

\section{Case \#2-3; Pursuing convenience for guests by food delivery}

Dinner is not served at four of the five hotels of Company G. The other one has a tavern, not operated by company $\mathrm{G}$ but it is a tenant, so guests can have dinner there. In all five hotels, breakfast is provided. Four of them use the lobby near the front desk as a place for breakfast.

The guests of these four hotels must go out to have dinner. Therefore, Company G made it possible for guests to request food delivery from the guestrooms. Guests order meals by calling at a restaurant in the neighborhood of each hotel. The restaurant delivers the meal to the guestroom and settles it. Guests can have dinner in their room. After meals, guests leave used dishes in the hallway in front of the rooms without washing. Hotel staff collect and wash dishes. The restaurant receives the dishes at the front desk. This way, guests who come back tired after work or vacation can have dinner in the room in a manner similar to room service.

\section{Discussions by these cases}

As mentioned above, Case \#1 is a case that contributes to reducing the denominator in the formula for calculating labor productivity. Case \#2 also contributes to increasing the numerator in the same formula.

In the simulation of Case \#1, the labor cost can be reduced. This is important in hotel management. However, the most important point in this simulation is not the labor cost reduction. This is because labor cost reduction has no effect on the value added that is the numerator in the formula for calculating labor productivity. In other words, reducing labor costs increases profits.

What is the most important point in Case \#1? It is a reduction in working hours. In Case \#1-1, one hotel of company $S$ was able to reduce its working hours by 1,642.5 hours per year. In Case \#1-2, it was possible to reduce 2,190 hours per year at one hotel of Company S. The total of them is 3,832.5 hours. If the entire Company $\mathrm{S}$ has 100 hotels,can be reduced to 383,250 of working hours. This value means 47,906.25 days (converted to 8 hours per day). Furthermore, if the annual working days of one employee are converted to 250 days, it means that about 191 employees can be reduced. In other words, it contributes to the reduction of the denominator in the formula for calculating labor productivity. Of course, this will lead to increased labor productivity. 
On the other hand, what about Case \#2. In hotels, increasing the number of guests is important. This is not only due to labor productivity, but also as a business, resulting in an increase in profits.

This increase in profits contributes to improved labor productivity. An increase in profits leads to an increase in added value. This is because the added value is simply measured by the formula "Revenue-Pre-benefit cost" as mentioned above. For example, in Case \#2-1, the Approach operation, which seems to be excessive service at first glance, led to the repurchasing of guests, that is, the expansion of revenue. Furthermore, in Case \#2-2 and Case \#2-3, by improving the convenience for the guests, company $\mathrm{G}$ also realized an increase in profits by acquiring repeaters.

\section{CONCLUSION AND LIMITATION}

The purpose of this paper is to clarify the implications that can be derived from the cases of hotel companies that have achieved high labor productivity. The implications of these cases and discussions are as follows.

Case \#1 can be said to be a "developed result". This is true, for example, removing bed legs, eliminating the need for physical keys and room telephones. And the device has improved labor productivity.

Case \# 2 can be said to be a true of "valuing guests". Of course, this should be limited to those that lead to revenue growth. It should also be limited to what the guest expects. In any case, excessive service is seen in Japanese hotels. However, the service that customers really want should be provided. Case \#2 is a good example.

The limitation of this paper is that the aspect of quantitative research is lacking. Qualitativeresearch have been conducted on these cases. However, quantitative research is indispensable in order to further deepen research and aim for theoretical construction. The author tries to collect related quantitative data in the future.

By the way, the two implications and viewpoints derived from these cases can be said to realize higher labor productivity when they are harmonized. It does not require an unreasonable challenge. This is because "ingenuity" and "valuing customers" are indispensable in every industry. 


\section{REFERENCES}

1. Japan Productivity Center (2018). International Comparison of Labor Productivity 2018 (Japanese), https://www.jpcnet.jp/intl_comparison/intl_comparison_2018.pdf (access; 15/May/2019).

2. Kajiura, A., (2016). "Productivity components and the reality of Added Value Distribution", Productivity improvement theory and practice (Japanese), Chuo Keizai-sha.

3. Mizuno, I. (2019). "Basic philosophy and purpose of new added value analysis", The Center of Productivity Comprehensive Research (ed.), Added value concept today for high added value management (Japanese), Japan Productivity Center.

4. OECD (2001). Measuring Productivity - Measurement of aggregate and industrylevel productivity growth (OECD Manual), OECD publishing.

5.. Policy Research Institute, Ministry of Finance, Japan (2015). Monthly Report of Financial Statistics (773) (Japanese).

6. Stewart, S. \& Johns, N. (1996). 'Total quality: an approach to managing productivity in the hotel industry', Johns, N. (ed.), Productivity Management in Hospitality and Tourism, Cassell. 